\title{
Svāhā in the Yagya: Meaning and Importance
}

\author{
Jitendra Kumar Mishra ${ }^{1}$ \\ ${ }^{1}$ Lecturer, Department of Vedic Studies and Sanskrit, Dev Sanskriti Vishwavidyalaya, Haridwar, India \\ *Corresponding. Email: jitendramishra1967@ gmail.com \\ https://doi.org/10.36018/ijyr.v4i1.70
}

\begin{abstract}
Svāhā is the word generally used in the Yagya when an offering is made to the fire. Generally in Yagya offering is made to the deity with deity Mantra; in this procedure, after the mantra is chanted, it is followed by the words 'Svāhā' and 'Idam-Na-Mama'. The offering is particularly put in the fire with the word 'Svāhā'. The present study explored the meaning of Svāhā through Indian Scripture. Description of Svāhā is present in all types of Indian literature i.e. Vedas, Upanishads, Puranas, Brahmana and well commented by Scholarly works. The study summarized the 3 types of implications of Svāhā i.e. 1) Svāhā is inseparable from Yagya Agni as it is depicted as the wife of Agni, 2) Svāhā is an essential portion of ritual i.e. Yagya is considered incomplete while offerings made without chanting of Svāhā; as Agni can not avail the offerings to deities, 3) Svāhā teaches how one should make offerings i.e. offerings shall be made with complete surrender, humility and sweetness full of emotions, after establishing oneself in wisdom, without ego, and attachment, and thus, only such offerings through Svāhā can be taken by Agni to the deities the for welfare of the individual and society.
\end{abstract}

Keywords. Svāhā, Agni, Yagya, Fire

\section{Introduction}

Svāhā is the word generally used in the Yagya when an offering is made to the fire. In Yagya before the offering is made to the deity, deity Mantra is chanted following by chanting of word 'Svāhā' and while chanting it, an offering is made which is followed by chanting of word 'Idam-Na-Mama' in some instances. The offering is particularly put in the fire with the word 'Svāhā'. The word 'IdamNa-mam' is used in Vedic Yagya where the outcome of the action is also offered to the deity of supreme; the meaning of it consists of the gist of the Yagya (1).
The word 'Svāhā' is particular important in Yagya during an offering. The present study attempted to explore the meaning and importance of Svāhā while offering to Agni (Yagya Fire) present in Indian Scripture. The study looked at the meaning and importance of Svāhā through various belief systems, Sanskrit dictionaries and in Indian Scriptures.

\section{Svāhā as defined in the Sanskrit dictionaries}

Svāhā as per Sanskrit dictionary is an adjective that is pronounced when leaving the offering in a sacrifice; also Svāhā is a word or mantra which is used at the time of offering to the gods. It also means the offering to all the deities. In addition, the 
dictionaries also reckoned Svāhā as Agni's (Fire God's) wife as described in Purana scriptures. Table 1 summarized the definition of Svāhā as described in different Sanskrit to English dictionaries. The definitions given in the dictionaries indicate two things specifically i.e. Svāhā is pronounced while offerings given to Yagya fire and She is personified Goddess and wife of Agni. Indian Scriptures also defines the meaning

\begin{tabular}{|c|c|}
\hline $\begin{array}{l}\text { Cologne Digital Sanskrit Dictionaries: } \\
\text { Benfey Sanskrit-English Dictionary (2) }\end{array}$ & $\begin{array}{l}\text { - An exclamation on offering to the gods } \\
\text { - } \quad \text { A personification of the preceding as the wife of the fire }\end{array}$ \\
\hline $\begin{array}{l}\text { Cologne Digital Sanskrit Dictionaries: } \\
\text { Cappeller Sanskrit-English Dictionary (3) }\end{array}$ & $\begin{array}{l}\text { - An exclaim used in making oblations = hail to } \\
\text { - } \quad \text { A personification of the daughter of Dakșa and wife of Agni }\end{array}$ \\
\hline $\begin{array}{l}\text { Cologne Digital Sanskrit Dictionaries: } \\
\text { Monier-Williams Sanskrit-English Dictionary } \\
\text { (4). }\end{array}$ & $\begin{array}{l}\text { - Hail! Hail to! May a blessing rest on!; To pronounce the exclamation Svāhā over } \\
\text { - An exclamation is used in making oblations to the gods; An oblation (offered to } \\
\text { Agni, Indra etc. } \\
\text { Oblation personified (as a daughter of Dakșa and wife of Agni; she is thought to } \\
\text { preside over burnt-offerings; her body is said to consist of the four Vedas, and her } \\
\text { limbs are the six Angas or members of the Veda; she is represented also as a wife } \\
\text { of the Rudra Paśu-pati) }\end{array}$ \\
\hline $\begin{array}{l}\text { Cologne Digital Sanskrit Dictionaries: } \\
\text { Yates Sanskrit-English Dictionary (5) }\end{array}$ & $\begin{array}{ll}\text { - } & \text { Exclamation on offering to the gods. } \\
\text { - } & \text { Wife of fire } \\
\text { - } & \text { Goddess of the Buddhists. }\end{array}$ \\
\hline $\begin{array}{l}\text { DDSA the practical Sanskrit-English } \\
\text { dictionary (6) }\end{array}$ & $\begin{array}{l}\text { - An oblation or offering made to all gods indiscriminately. } \\
\text { - Name of the wife of Agni } \\
\text { - An exclamation used in offering oblation to the gods e.g - इन्द्राय स्वाहा (indrāya } \\
\text { svāhā); अग्नये स्वाहा (agnaye svāhā) etc }\end{array}$ \\
\hline $\begin{array}{l}\text { Cologne Digital Sanskrit Dictionaries: } \\
\text { Shabda-Sagara Sanskrit-English Dictionary } \\
\text { (7) }\end{array}$ & $\begin{array}{l}\text { - An exclamation uttered at the time of making an offering to the gods } \\
\text { - A personification of the preceding, as the wife of fire, and goddess presiding over } \\
\text { burnt offerings } \\
\text { - } \quad \text { An oblation made to Gods indiscriminately. } \\
\text { - A female divinity, peculiar to the Bauddhas }\end{array}$ \\
\hline
\end{tabular}

Table 1. Definitions of Svāhā as described in different Sanskrit to English dictionaries.

\section{Svāhā in the different Belief system}

Vedic system one of the meanings of Svāhā is the oblation. In the Buddhist literature, it also indicates interjection and 'hail!' in mantras. In the Tibetan language, it is translated as 'so be it'. It is also pronounced as 'Soha' and chanted whenever sacrifices are made. In the Vedic system Svāhā is also recognized as the wife of Agni. In the Jainism also Svāhā is known as the wife of Agni, who is one of the Dikpāla (Guardians deity) (8).

\section{Description of Svāhā in the Puranas}

Vedas described that while reciting the mantra for the purpose of invoking the deity, reciting 'Svāhā' and offering the prescribed Havan material to the deities reaches to them through fire deity. This is also reflected in stories from Purana. The connection between Yagya Fire and Svāhā is also described in the Shrimad Bhagavata Purana and ShivPurana in the rhetorical story that 'Svāhā' was the daughter of Daksha Prajapati who was married to Agni (Fire deity). Various Purana mentioned same story depicting Svāhā as wife of Agni as given in Table 3. 


\begin{tabular}{|c|c|c|}
\hline Purana & Details & References \\
\hline Shiva Purana & Rudra saṃhitā Sṛțti-khaṇ̣a, chapter - description of the Creation & 9 \\
\hline \multirow[t]{3}{*}{ Bhāgavata-purāṇa } & Khand IV Adhyay 1 Sloka 60 & 10 \\
\hline & Prakriya Pada Chapter 1 Sloka 62 & \\
\hline & Anușaniga-pāda Chapter 9 Sloka 56 & \\
\hline \multirow[t]{2}{*}{ Brahmanda Purana } & Chapter 10 Sloka 81 & 11 \\
\hline & $\begin{array}{l}\text { Part Upodghāta-pāda Chapter } 3 \text { (The race of Dharma: three attributes of the self-born God) } \\
\text { Sloka } 25\end{array}$ & \\
\hline Vișṇu-purāṇa & Book I, Chapter 7 (Production of the mind-born sons of Brahma) & 12 \\
\hline \multirow[t]{2}{*}{ Vāyu-purāṇa } & Chapter 10 (Manvantaras) Sloka 28 & \multirow{2}{*}{13} \\
\hline & Chapter 29 (Progeny of Agni) Sloka 1 & \\
\hline
\end{tabular}

In Indian culture, wife is considered as half body of the husband. And hence, the hidden meaning of the story is the strong relation of 'Svāhā' during oblation in the Yagya Fire. In Yagya, Agnidev is also known as the carrier of all offerings to the diety. It is also an interesting fact that Agnidev accepts offerings only through his wife 'Svāhā' and through Agnidev the same offerings is received by the invoked deity.

Apart from this, another interesting story is also related to the origin of Svāhā. Svāhā was an art of nature, whose marriage with Agni was performed at the request of the gods. Lord Shri Krishna himself had given this boon to Svāhā that only through him the deities would be able to receive the offerings. It was clear that the word 'Svāhā has an important place in Yagya and when offerings have to be made in the Yagya fire.

Other Purana stories also described other roles of Goddess Svāhā as described as following: As per Kamakoti Mandali Svāhā and as per the ritual Durgāpūjātattva, Svāhā is one of the goddesses worshipped during ritual Āvaraṇapūjā (8). In MatsyaPurana, Svāhā is also one of the MātṛkāŚaktis goddess created by Mahārudra to control the plague of demons (8). As per Pādma-purāṇa, Svāhā is the consort of Rudra (Paśupati (Rudra, Lord Siva)
(8). As per Mahābhārata Vana Parva, Chapter 219, Verse 22, Svāhā is a daughter of Bṛihaspati (8). However, the references of Svāhā as wife of Agni are many more in various Puranas clearly indicating universal acceptance of Svāhā as wife of Agni (Table 3) indicating an inseparable role of Svāhā from Agni.

\section{Svāhā in Indian Scriptures}

Meaning of Svāhā as described in nirukta

Nirukta (Chapter 8 Episode 20) described definition of Svāhā as - स्वाहाकृतय:। स्वाहेत्येतत् सु आहेति वा । स्वा वागाहेति वा। स्वयं प्राहेति वा । स्वाहुतं हविर्जुहोतीति वा । तासामेषा भवति ॥ (Svāhākrutayaha Swahetyetastu aaheti va swaa vaagaaheti vaa svam praheti va swahutam havirjuhoteeti vaa taasaameshaa bhavati) (14). Its meaning is described in Table 2. 


\begin{tabular}{ll}
\hline Svāhā definition as per Nirukta & Meaning \\
\hline सु आहेति वा (Su aaheti vaa) & Gentle, sweet, benevolent and dear word one should speak \\
\hline स्वा वागाहेति वा (Sava Vaagaaheti vaa) & $\begin{array}{l}\text { One should always speak voice which coming from heart after establishing } \\
\text { oneself in wisdom }\end{array}$ \\
\hline स्वयं प्राहेति वा (Swayam Praheti vaa) & One should call one's own things own, not others' \\
\hline स्वाहुतं हवि (Swaahutam havi) & One should always offer havi which is thoroughly cleansed \\
\hline Table 2. The meaning of Svāhā as per Nirukta &
\end{tabular}

Table 2. The meaning of Svāhā as per Nirukta

Meaning of Svāhā as described as per the Vachasptya Kosh (15)

It says meaning of Svāhā which is also saif in the Nirukt as described above i.e. स्वाहा - अव्य. सु+ वा + हे डा | In addition it also refers Svāhā definition given in the Amar Kosh by stating देवोहेयेन हयीस्वाने अमर:, and as per Amar kosh it means wife of agni and also says it should be for offering havi to Deities.

\section{Svāhā as referred in Vedic literature \& by Sages \&} Scholars

Rigveda 1.13.12 states स्वाहा यज्ञ कृणोतं। (Svāhā Yagya Krinotam) - meaning Yagya offerings has to be performed with recitation of 'Svāhā' (16). In the book Ānanda-Rāmāyaṇa kā sāṃskrtika adhyayana, the author described the literal meaning of Svāhā that is the right renunciation of self and visarjan (sacrifice) (17). In Upanishad, the word Svāhā means to surrender - dedicate oneself with all one's strength in the spirit of benevolence (18). The meaning of 'Svāhā' as per Mantra Mahavigyan book - स्वाहा चात्मसमर्पणमिति (Svāhā Chatmasarpanmiti) states 'The meaning of the word Svāhā is to surrender to supreme force. In this way, the word 'Svāhā' is a self-statement that reinforces the spirit of renunciation of ego-attachment with taking refuge under supreme force' (19).

\section{Discussion}

Rigveda Mandal 10 Sukta 110 Mantra 11 also states the importance of offering Havi (Hawan Samagri and other oblation items) along with chanting of 'Svāhā' (20). It states स्वाहाकृतं हविरदन्तु देवा: It means Havi offered with Svāhā in the Yagya Fire shall be accepted by Deities. Similarly, Shatpath Brahamana Kāṇ̣̣a I, adhyāya 5, brāhmaṇa 3, Slok 13 also indicated that oblation made with chanting of word 'Svāhā' makes the offering complete and implies that without chanting of word 'Svāhā', Oblations offered considered incomplete (21). Thus, oblations of Havi (offerings such as Hawan Samagri, Ghee, etc) should be offered in the Yagya fire along with chanting of Vedic-Mantras ending with sound 'Svāhā'.

Scriptures described Svāhā should be chanted during oblations which are aimed at deities, while Svadha should be chanted during oblations which are aimed at Pitrs. This is well explained in Brahmāṇụa-purāṇa Part Upodghāta-pāda Chapter 3 (The race of Dharma: three attributes of the selfborn God) Sloka 116, which described that in the Mantras of the rites of Pitrss, the word Svadhā is added and in the Yajña rites of Devas the word Svāhā is recited (11).

Besides, philosophical, ritualistic, and spiritual implications, Svāhā have more dipper utility in Vedic and Tantric spiritual practices. The author Ranajīta Saha in her book Sahaja siddha described that 'the secret words are signs - स्वधा (swadha), स्वाहा 
(avaha), वषट (vasat), वेद (veda), वाट (vat), Svāhā, vasat, veda vat etc., and the meaning of which is still conjecture' (22). Hence, it hints that these signs have very dipper utility in Vedic and Tantric spiritual practices.

\section{Conclusion}

Description of Svāhā is present in all types of Indian literature i.e. Vedas, Upanishads, Puranas, Brahmana and well commented by Scholarly works (1-22). It is present all over scriptural history. In addition, the indication of utility of Svāhā in Tantric and Vedic spiritual practices attracts the potential of future studies. The present paper, Summarily derived 3 types of implications of Svāhā i.e. 1) Svāhā is inseparable from Yagya Agni as it is depicted as wife of Agni (9-13), 2) Svāhā is essential portion of ritual i.e. Yagya is considered incomplete while offerings made without chanting of without Svāhā; as Agni can not avail the offerings to deities (16, 20-21), 3) Svāhā teaches how one should make offerings i.e. Offerings shall be made with complete surrender, humility and sweetness full of emotions, after establishing oneself in wisdom, without ego, and attachment, and thus, only such offerings through Svāhā can be taken by Agni to the deities for welfare of the society $(14,17-19)$.

\section{References}

1. Sharma GK, Sharma PG. Deciphering 'Idam-na-mama- This is not mine' as the core tenet of a Yagya based life-style. Interdis. J of Yagya Res. 2019;2(1):29-32. https://doi.org/10.36018/ijyr.v2i1.32

2. Benfey, T.. A Sanskrit-English dictionary: with references to the best editions of Sanskrit authors and etymologies and comparisons of cognate words chiefly in Greek, Latin, Gothic, and Anglo-Saxon. London, Longmans, Green, and Co., 1866.

3. CAPPELLER, C. A Sanskrit-English dictionary: based upon the St. Petersburg lexicons. Strassburg, Trübner, 1891.

https://doi.org/10.1515/9783111556871

4. Bibliographic entry: MONIER-WILLIAMS, M. A SanskritEnglish dictionary: Etymologically and philologically arranged with special reference to Cognate indo-european languages. Oxford, The Clarendon Press, 1899

5. Yates, W. A dictionary in Sanscrit and English: designed for the use of private students and of Indian colleges and schools. Calcutta, Printed at the Baptist Mission Press., 1846

6. The Digital South Asia Library is a program of the University of Chicago and the Center for Research Libraries, 2015. The URL of this page is: https://dsal.uchicago.edu/index.html

7. Bhaț̣āāarya, J. V. A comprehensive Sanskrit-English lexicon: chiefly based on Professor Horace Hayman Wilson's Sanskrit-English Dictionary and compiled from various recent authorities for the use of schools and colleges. Calcutta, Calcutta Press, 1900.

8. Wisdom Library. Svāhā, Svāhā, Svāha: 20 definitions, 2008. Available from - https://www.wisdomlib.org/definition/Svāhā

9. J.L. SHASTRI. The Siva Purana. MOTILAL BANARSIDASS PUBLISHERS PVT. LTD. 1950. ISBN: 9788120803398. Available from https://archive.org/details/SivaPuranaJ.L.ShastriPart1/page/n5 Imode/2up

10. A.C. Bhaktivedanta Swami Prabhupāda. SrimadBhagavatam: Bhagavata Purana. The Bhaktivedanta Book Trust International, Inc. 1st edition. 2010

11. G.V. Tagare. The Brahmanda Purana. MOTILAL BANARSIDASS PUBLISHERS PVT. LTD. 1958 ISBN-10: 8120838246

12. Horace Hayman Wilson. The Vishnu Purana. London : Trübner \& co. 1864. ISBN-10: 8171102127.

13. G.V. Tagare. The Vayu Purana. MOTILAL BANARSIDASS PUBLISHERS PVT. LTD. 1987 ISBN-10: 81-208-0332-9

14. R G Bhadkamkar (Ed.) The Nirukta of Yaska. The Department of Public Instruction Bombay. Bhandarkar Oriental Research Institute, Pune. 1942. Page No 886. Available from https://archive.org/details/in.ernet.dli.2015.485860

15. Tarakavachaspati, ShriTaranatha. vachaspatayam, (brahat sanskritabhidhanam); vol. 6. chowkhambha sanskrit series office Varanasi- 1. 1962; pg. 989 
16. Vedamurti Taponishtha Pt. Shriram Sharma Acharya and Bhagwatidevi Sharma (Editor). Rigveda Samhita (Revised Edition). Yug Nirman Yojana Extension Trust, Gayatri Tapobhoomi, Mathura-281003. 2013. Part Page No

17. Guptā, Aruṇā. Ānanda-Rāmāyaṇa kā sāṃskṛtika adhyayana. India: Îsțarna Buka Lin̉karsa, 1984. Page 147.

18. 108 Upaniṣad: sarala Hindī bhārtha sahita. India: Brahmavarcasa, 1997. Page 487

19. Gautama, Camanalāla. Pramukha devī devatāyom kī vaijñānika sādhana prạ̣āiyam̆. India: Saṃskrti Saṃsthāna, 1972. Page 243.
20. Vedamurti Taponishtha Pt. Shriram Sharma Acharya and Bhagwatidevi Sharma (Editor). Rigveda Samhita (Revised Edition). Yug Nirman Yojana Extension Trust, Gayatri Tapobhoomi, Mathura-281003. 2013. Part Page No

21. Julius Eggeling. Satapatha Brahmana. Oxford, The Clarendon Press. 1882. Available from https://archive.org/details/satapathabrahmana00egge

22. Sāhā, Raṇajīta. Sahaja siddha: sādhanā evaṃ sarjanā. India: Vāṇī Prakāśana, 1980. Page 58 